Portland State University

PDXScholar

1979

\title{
Oregon Chapter, National Association of Social Workers : membership study
}

\author{
Gale Brewer \\ Portland State University \\ Leslie Hayashida \\ Portland State University \\ Kathy Lam \\ Portland State University \\ Adrian Navarro \\ Portland State University
}

Follow this and additional works at: https://pdxscholar.library.pdx.edu/open_access_etds

Part of the Social Work Commons

Let us know how access to this document benefits you.

\section{Recommended Citation}

Brewer, Gale; Hayashida, Leslie; Lam, Kathy; and Navarro, Adrian, "Oregon Chapter, National Association of Social Workers : membership study" (1979). Dissertations and Theses. Paper 2823.

https://doi.org/10.15760/etd.2817

This Thesis is brought to you for free and open access. It has been accepted for inclusion in Dissertations and Theses by an authorized administrator of PDXScholar. Please contact us if we can make this document more accessible: pdxscholar@pdx.edu. 
OREGON CHAPTER, NATIONAL ASSOCIATION OF SOCIAL WORKERS MEMBERSHIP STUDY

\author{
by \\ GALE BREWER \\ LESLIE HAYASHIDA \\ KATHY LAM \\ ADRIAN NAVARRO
}

A practicum submitted in partial fulfillment of the requirements for the degree of

MASTER OF SOCIAL WORK

Portland State University

1979 
TO THE OFFICE OF GRADUATE STUDIES AND RESEARCH:

The research practicum advisor approves the practicum of Gale Brewer, Leslie Hayashida, Kathy Lam, and Adrian Navarro presented May, 1979

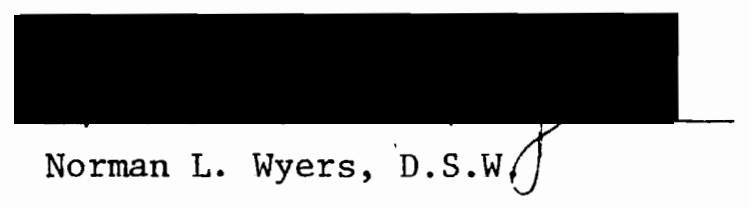




\section{ACKNOWLEDGEMENTS}

We wish to thank the following persons for their assistance in this study. First, we wish to thank our advisor, Dr. Norman L. Wyers, for his assistance, advice, and encouragement. We would like to thank Nancy Koroloff for her time and advice regarding the initial questionnaire development, and for her assistance in resolving problems that arose in analyzing the data.

We would also like to thank Linda Dreyer, Dr. Frank Miles, Dr. James Breedlove, and Dr. Gerald Frey for suggestions on improving the questionnaire.

We want to extend our thanks to Gary Dominick, former Director of the Oregon Chapter, National Association of Social Workers, for his support and for his assistance in obtaining support from the Chapter.

Finally, we want to give special thanks to Phil Dube, secretary of the Chapter, for his time and assistance in obtaining information necessary for this study. 
TABLE OF CONTENTS

PAGE

ACKNOWLEDGEMENTS . . . . . . . . . . . . . . . . . . . i ii

LIST OF TABLES . . . . . . . . . . . . . . . . . . . . vi vi

CHAPTER

I INTRODUCTION . . . . . . . . . . . . . . . . 1

II REVIEW OF THE LITERATURE . . . . . . . . . . . . 4

Historica1 Background . . . . . . . . . 5

A Research Project, by the 8 Ohio Chapter, NASW . . . . . . . . .

Factors Related to Joining and With- 10 drawing from Organizations . . . . . . .

Summary . . . . . . . . . . . . . 13

III METHODOLOGY . . . . . . . . . . . . . . . . 14

Focus of Study . . . . . . . . . . . . 14

Questionnaire Pre-test . . . . . . . . 15

Population . . . . . . . . . . . . . 16

Instrument . . . . . . . . . . . . . 17

Collection of Data.............. 19

Limitations of the Study . . . . . . . . 20

IV RESULTS . . . . . . . . . . . . . . . 22

Pre-Questionnaire Screening . . . . . . . . 22

Demographic Data . . . . . . . . . . 24 


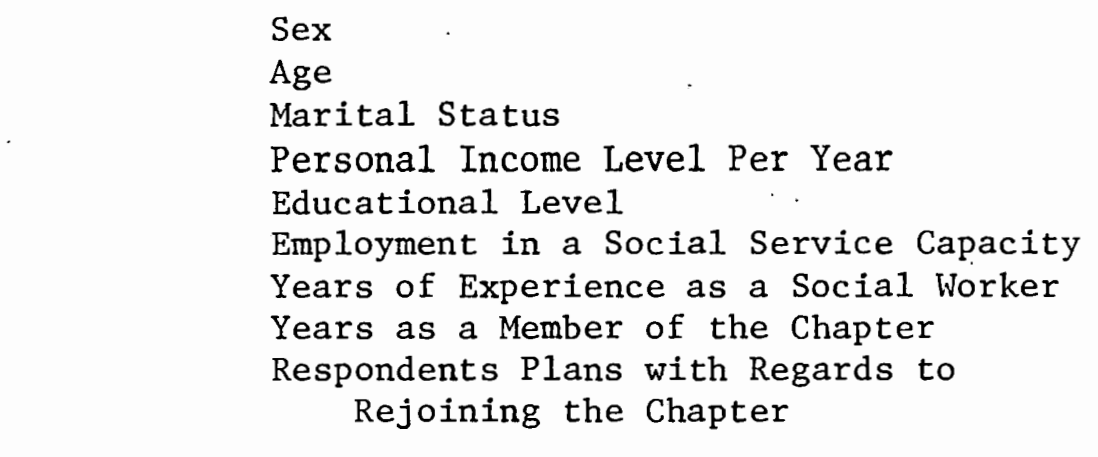

Knowledge and Attitudes . . . . . . . . .

Membership Dues

Chapter Funds

Professional Prestige and Social Issues Legislation

Member Input

Summary and Comments . . . . . . . . 39

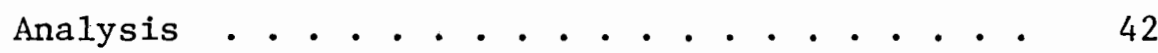

V SUMMARY AND RECOMMENDATIONS . . . . . . . . . . . 46

Purpose . . . . . . . . . . . . . . . 46

Literature Summary . . . . . . . . . . 46

Summary of Methodology . . . . . . . . . 47

Summary of Findings . . . . . . . . . . 47

Limitations of Study . . . . . . . . . . . 48

Conclusion . . . . . . . . . . . . . . 48

BIBLIOGRAPHY . . . . . . . . . . . . . . . . . . .

APPENDIX

A PILOT STUDY QUESTIONNAIRE . . . . . . . . . . . 52

B LETTERS SENT TO STUDY PARTICIPANTS . . . . . . . . . 56

C FINAL QUESTIONNAIRE . . . . . . . . . . . . . 58 


\section{LIST OF TABLES}

TABLE

PAGE

I Members who Withdrew from Oregon Chapter, NASW, as a

Result of Leaving the Profession of Social Work,

by Number and Percent . . . . . . . . . . .

II Marital Status of Members who Withdrew from Oregon

Chapter, NASW, by Number and Percent . . . . . .

II Personal Income Level Per Year of Members who Withdrew

from Oregon Chapter, NASW, by Number and Percent .

IV Acceptable Level of Dues as Indicated by Members who

Withdrew from Oregon Chapter, NASW, as a Result

of the High Cost of Dues, by Number and Percent..

V Benefits Utilized by Members who Withdrew from Oregon

Chapter, NASW, by Number and Percent . . . . . .

VI Attitudes of Members who Withdrew from Oregon Chapter,

NASW, Regarding the Chapter's Concern with Pro-

fessionai Prestige, by Number and Percent . . . .

VII Attitudes of Members who Withdrew from Oregon Chapter,

NASW, Regarding the Chapter's Concern with Social

Issues, by Number and Percent . . . . . . . . .

VIII Attitudes of Members who Withdrew from Oregon Chapter, NASW, Regarding what the Chapter Should be Concerned with in Relation to Professional Prestige and Social Issues, by Number and Percent . . . . 
IX Knowledge of Legislation Supported by the Chapter as

Indicated by Members who Withdrew from Oregon Chapter, NASW, by Number and Percent . . . . . . 34

X Satisfaction with Legislation Supported by the Chapter as Indicated by Members who Withdrew from Oregon Chapter, NASW, by Number and Percent . . . . . . 35

XI Members who Withdrew from Oregon Chapter, NASW, as a Result of a Lack of Leadership, by Number and Percent. . . . . . . . . . . . . 36

XII The Extent to which Members, who Withdrew from Oregon Chapter, NASW, Voted on Chapter Issues, by Number and Percent . . . . . . . . . . . . . . .

XIII Perceptions Regarding Channels of Input to the Chapter as Indicated by Members who Withdrew from Oregon Chapter, NASW, by Number and Percent . . . . . .

XIV Reasons for Withdrawal from the Chapter as Indicated

by Members who Withdrew from Oregon Chapter, NASW, by Number and Percent . . . . . . . . . . . . 


\section{CHAPTER I}

\section{INTRODUCTION}

The purpose of this practicum is to present a descriptive analysis of possible causes related to the drop-out rate in the Oregon Chapter, National Association of Social Workers (NASW) during the period between March of 1977 to March of 1978. Initial interest and involvement for this practicum was generated by a classroom announcement from Norman L. Wyers, D.S.W., Associate Professor at Portland State University School of Social Work. The announcement indicated that the Oregon Chapter, NASW, was interested in studying this drop-out rate. Throughout this practicum, the Oregon Chapter, NASW will be referred to as the Chapter.

NASW is a professional organization to which individuals in the social work profession can belong. A discussion of the origin and purposes of the organization will be presented in the literature review in Chapter II. Since the study was concerned only with the Oregon Chapter, NASW, particular attention will be given to its historical development. In addition, the review of the literature will focus on reasons why people wish to belong to organizations and on factors which may be involved in members' decisions to withdraw from an organization. A research project similar to this study, which was done in the state of Ohio by Platt and Kalvin, will also be presented. 
Specifically, this practicum will examine several factors which may be involved in members' decisions to withdraw from the Chapter. These six factors are: membership dues, allocation of funds, the Chapter's role in promoting legislation, the Chapter's emphasis on professional prestige and/or social issues, leadership within the Chapter, and members' participation in the Chapter. Those members who have moved to another state or those who left the profession of social work have been identified. These members did not participate in the practicum because their reason for withdrawing differed from the six factors previously specified.

In relation to membership dues, the focus was directed towards determining whether members believed the cost of dues was too high. Also covered in this area were benefits gained from affiliation with the organization. Here members were questioned as to whether they believed their dues brought adequate benefits. In relation to the allocation of funds, the study directed its attention to members knowledge of how funds 'were allocated and members' satisfaction with this allocation. With regards to promoting legislation, the study focused on members' knowledge of legislation supported by the Chapter and their satisfaction with legislation supported by the Chapter. In the area of professional prestige and/or social issues, the study directed its focus towards determining if members believed there was an overemphasis in either area. In gaining further information in this area, members were asked to indicate their preference. Regarding leadership within the Chapter, the focus was directed towards determining whether 
members believed there was a lack of leadership in the Chapter. $\Lambda 1$ so to be covered in this area is the organizational structure and members' awareness of it. In examining members' participation in the Chapter, the study focused on members' channels of participation. Also considered in this area was the Chapter's responsiveness to its members' needs. 
In reviewing the literature, no studies on drop-out rates of organizations were located; however, it was found that there exists literature on the characteristics of organizations. Through contact with NASW, one study was located which was directed specifically towards drop-out rates. That study was conducted by the Ohio Chapter.

Because there was no literature specifically discussing drop-out rates, other topics covered were: characteristics of persons attracted to groups, social prestige, leadership of organizations, economics, social mobility, membership dues, and members' input. This review, therefore, includes a survey of the literature, a summary of contact with the Chapter and, finally, a summary of contact with other professional organizations in the Portland area.

Contact with these other professional organizations involved asking personnel if they were aware of any studies conducted on their membership drop-out rates. The organizations contacted were the oregon Dental Association, the Oregon Education Association, the Oregon Nurses Association, the Oregon Medical Association and the Oregon Psychoanalytic Foundation. A11 representatives of these organizations testified that there were no known studies conducted on their drop-out rates. From this, it was concluded that in Oregon there have been no studies on drop-out rates, leaving no findings to draw on. 
This chapter will present background information on the formation of the Chapter along with a discussion of NASW on the national level. A discussion of the Ohio Study will also be included. Finally, there will be presented a discussion of reasons which result in people joining organizations and possible causes for their leaving organizations, as derived from the pertinent literature.

\section{HISTORICAL BACKGROUND}

The American Association of Social Workers (AASW) of Oregon was created in 1933. ${ }^{1}$ The Oregon Chapter, AASW was located in Portland. The Chapter enrolled members from a list of social workers who belonged to the National American Association of Social Workers. ${ }^{2}$ From its inception, the Oregon Chapter, AASW dealt with topics which concerned the state of Oregon during the depression. The Oregon Chapter, AASW was to study unemployment relief and to begin the formation of an Oregon State Department of Public Welfare. ${ }^{3}$

The Portland School of Social Work in Portland was created in 1919. It was designed to educate and train aspirants to the field of social work. In 1932, the Portland School of Social Work was closed due to reorganization of the Oregon State Board of Higher Education. 4

${ }^{1}$ Allen East, A History of the Oregon Chapter, American Association of Social Workers Until its Merger with the National Association of Social Workers $(1921-1955)$, (Eugene, Oregon, American Association of Social Workers, 1956), p. 12 .

$$
\begin{aligned}
& 2 \text { Ibid., p. } 5 . \\
& { }^{3} \text { Ibid., p. } 8 . \\
& { }^{4} \text { Ibid., p. } 4 .
\end{aligned}
$$


The field of social work at that time was regarded as a second priority to the economics of that period. This general attitude prevailed throughout the country, which at that time was experiencing the depression of the $1930^{\prime} \mathrm{s}$. As a result of the closure of the Portland School of Social Work, many people entered the social services without a background for such work. ${ }^{5}$ Since there was no school to provide formal training in social work, the oregon Chapter, AASW undertook the study of offering training for new staff, workers in agencies until the Portland School of Social Work reopened. 6 No further information is available as to whether this was accomplished.

A project started in 1932 by the Portland School of Social Work, before it closed, involved the problem of whom to admit to AASW. This was recommended for future study by the Oregon Chapter, AASW in 1933. It was decided that only workers who were formally trained by experienced social workers would be eligible. ${ }^{7}$ The remaining history of the Oregon Chapter, AASW is scattered and undocumented. 8

In 1955, the Oregon Chapter, AASW was absorbed into the nationally reorganized National Association of Social Horkers (NASW) and became the oregon Chapter, NASW. ${ }^{9}$ NASW was created to unify the social work profession, advance professional practice and standards, and

$$
\begin{aligned}
& { }^{5} \text { Ibid., p. } 9 . \\
& { }^{6} \text { Ibid. } \\
& { }^{7} \text { Ibid. } \\
& { }^{8} \text { Ibid., p. } 12 . \\
& { }^{9} \text { Ibid., p. } 20 .
\end{aligned}
$$


improve social service policies and programs in service to the community. ${ }^{10}$ It has been said that NASW could be envisioned as the organization which contains the body of professional and student social workers whose principal concern is the betterment of society. ${ }^{11}$ In 1978, NASW had a professional membership of over 78,000 persons. ${ }^{12}$ There are presently three categories of membership within NASW. Regular membership requires the minimum of a Bachelor of Arts Degree in Social Work. Associate membership is available to those holding a non-social work degree and currently employed in a social work capacity. Student membership is available to social work students in accredited graduate or undergraduate programs. ${ }^{13}$ These three categories enable many people involved in a professional social work capacity to join NASW.

NASW has four primary functions. They are: professional development of members, creation and maintenance of social work practice, advancement of sound social policies and programs, and membership services. The specified goals for the 1970 decade are the eradication of the social problems of racism and poverty. Their six key program priorities are: social services, income maintenance, health and mental

${ }^{10}$ National Association of Social Workers, The 1978 National Association of Social Workers Professional Social Workers Directory (Washington, D.C.: National Association of Social Workers, Inc., 1978), p. vii.

$11_{\text {Bertram M. Beck, "Professional Associations: National Associa- }}$ tion of Social Workers", in Encyclopedia of Social Work, $17 \mathrm{th}$ ed., 2 vols., ed. John B. Turner (Washington, D.C.: National Association of Social Workers, Inc., 1977), p. 1088.

12 National Association of Social Workers, Directory, p. vii. ${ }^{13}$ Ibid. 
health, man and woman power, adult and juvenile justice systems, and women in social welfare. 14

A RESEARCH PROJECT BY THE OHIO CHAPTER, NASW

A research project was recently conducted on the topic of why social workers terminated their NASW membership between 1974 to 1978 by the Ohio Chapter, NASW. The project report was submitted by Carol Bowen Platt, Ohio Chapter Membership Chairperson and Mary Kalvin, District 非6 Public Relations Chairperson. ${ }^{15}$ The purposes of the research were to discover why social workers terminate their membership; to develop a baseline for further research; to make recommendations available to local, state, and national membership committees; and to discover ways to make NASW more relevant to its members. ${ }^{16}$

The researchers in the Ohio study were able to locate sixty members who had terminated their membership. This was from a total of one hundred and thirty names of members who had withdrawn within the time period of 1974 to $1978 .{ }^{17}$ The total response rate in this survey was forty-five (seventy-five percent). 18

\section{${ }^{14}$ Ibid., p. vii.}

${ }^{15}$ Carol Bowen Platt and Mary Kalvin, "Why do Social Workers Terminate their National Association of Social Work Membership: A Research Project 1974 - 1978", a paper submitted to the National Association of Social Workers (Columbus, Ohio, 29 December, 1978).

$$
\begin{aligned}
& 16^{\text {Ibid., p. } 1 .} \\
& 17 \text { Ibid. } \\
& 18_{\text {Ibid., p. } 2 .}
\end{aligned}
$$


The Ohio researchers asked for data from respondents through the use of a return post card. The data asked for included: when the membership was dropped; why the membership was dropped, with three specific reasons to be checked: dues, no longer working, and no longer meeting needs; how was NASW no longer meeting needs, if this was a reason for termination; and what would it take to get the respondent to rejoin NASW. ${ }^{19}$

In the results section of the Ohio research project, the researchers listed six reasons for termination. They are: dues, retirement, membership no longer meets needs, health, deceased, and membership transfer to Kentucky. ${ }^{20}$ Two results specific to this piece of research were that the personal contact with social workers stimulated four reapplications for membership and the interaction aided in reducing some misconceptions regarding membership and mailing problems. ${ }^{21}$

Bowen and Platt made six recommendations as a result of their survey. The first four pertained to retirees. First, they recommended a reduced dues rate for retired social workers. Then they recommended sending a letter encouraging reapplication of retirees. They also recommended special mailings for retirees and encouragement of retirees to share their experiences with professionals just beginning their careers. The final two recommendations made were to set up a local information and referral hot line for relevant professional issues and

$$
\begin{aligned}
& { }^{19} \text { Ibid., p. } 2 \\
& 20 \text { Ibid. } \\
& { }^{21} \text { Ibid., p. } 6
\end{aligned}
$$


and to conduct another survey in one year. 22 Following these recommendations, these researchers state, "It is important that NASW be in touch with why members terminate, keeping up with the pulse of the professional community to maintain NASW as a viable professional organization of social workers." 23

No other studies on membership drop-out rates of NASW are known at this time. Cynthia W. Pratt, Membership Development Coordinator at the NASW national headquarters, has confirmed this conclusion. 24

FACTORS RELATED TO JOINING AND WITHDRAWING FROM ORGANIZATIONS

Napier and Gershenfeld have identified characteristics of persons attracted to group membership. They state, "It has been found that when a member is attracted to the group, he is more flexible in accepting others' opinions, and he will attempt to influence the other's more." 25 Alexis de Tócqueville observed over one hundred and forty years ago that Americans have a predilection for associations, and professionals are no exception. 26 This can be attested to by the 1ong historical development of AASW which was previously discussed.

${ }^{22}$ Ibid., pp. 6-7.

${ }^{23}$ Ibid., p. 7 .

${ }^{24}$ Telephone interview with Cynthia W. Pratt, National Association of Social Workers, February 1979.

25 Rodney E. Napier and Matti K. Gershenfeld, Groups: Theory and Experience (Boston: Houghton Mifflin Company, 1973), p. 87.

${ }^{26}$ Alexis de Tocqueville, Democracy in America (1835), trans. Henry Steele Commager (New York: Oxford University Press, 1947), p. 138 . 
Individuals may join an organization in hopes of obtaining economic stability. Efforts in this area are being pursued by NASW, in that NASW has set minimum starting salaries for social workers with different certifications. ${ }^{27}$ NASW is also involved in efforts to gain recognition for social workers as vendors of services who can be reimbursed by public or private insurance companies. ${ }^{28}$

Individuals may be influenced by a variety of other motivational factors which cause them to join organizations. These motivational factors may range from a desire for upward mobility and the increasing of one's job skills to a desire to gain social prestige in one's career. 29

When an individual or group of individuals decide to leave an organization, the rationale behind their leaving may affect the future of the organization. Napier and Gershenfeld explain that a person considers leaving a group when the forces of attraction are decreased or negative, when his own needs for satisfaction are reduced, when the group becomes less suitable as a means for satisfying existing needs, or when the group acquires unpleasant properties. 30

NASW assesses yearly dues of its members. State chapters receive a fixed portion of the dues of each member and, within broad limits,
27 Beck, "Professional Associations", p. 1091. 28 Ibid.

${ }^{29}$ Alfred Kadushin, "Prestige of Social Work, Facts and Factors", Social Work 3(April 1958): 41.

${ }^{30}$ Napier and Gershenfeld, Groups, p. 61

${ }^{31}$ Beck, "Professional Associations", p. 1092. 
are free to expend the funds as the chapter designates. ${ }^{31}$ The annual dues rate of NASW was raised in July of 1978. Dues were raised from $\$ 60.00$ to $\$ 90.00$ for regular members, from $\$ 35.00$ to $\$ 72.00$ for associate members, and from $\$ 15.00$ to $\$ 22.00$ for students. This is important in light of what Lindzey and Aronson have to say regarding such raises. They say that borderline members are pushed over and out when the precarious balance is disturbed, such as, when the meeting time is changed or dues are raised even a small amount. 32

Lack of leadership in an organization may cause members to leave the organization. 33 Members who leave may be accustomed to having a well-defined leadership structure. Lack of leadership may cause subgroups to form. These subgroups may then meet the needs of individuals whose needs are not met by the organization at Iarge. ${ }^{34}$ These subgroups may then leave the larger organization.

Another topic related to leadership is that of member input. Member input may be lacking or ignored by an organization's ruling structure. Input, such as suggestions or criticisms, may have no impact within the organization. Decisions and leadership are assumed by a governing few who disregard member input. 35 Hence, dissatisfaction of members may result.

31 Beck, "Professional Associations", p. 1092.

${ }^{32}$ Gardner Lindzey and Elliot Aronson, The Handbook of Social Psychology, 2nd ed. (Reading, Mass.: Addison-Wesley Publishing Company, 1969), p. 125.

33 Napier and Gershenfeld, Groups, p. 62.

${ }^{34}$ Ibid., p. 63.

${ }^{35}$ Ibid. 
Factors causing people to join and withdraw from organizations are numerous; however, reasons for withdrawing, in particular, have not been studied widely. The material presented above are ideas which have been drawn from pertinent literature and are not widely researched.

\section{SUMMARY}

In summary, it must be noted that there is very little research which has been done on drop-out rates. In reviewing the literature, no studies on drop-out rates were located. In Oregon, there is no research on drop-out rates as verified through contacting local professional associations. Only one study was located on drop-out rates within NASW. Factors have been delineated in the literature which may cause people to join or withdraw from organizations; however, research on these factors is scarce. 
CHAPTER III

METHODOLOGY

This chapter, describing the methodology of this research practicum, is divided into six segments. The first five segments present the focus of the study, a discussion of the pre-test of the questionnaire, a description of the population, a description of the testing instrument, and a discussion of the data collection process. The final segment of the methodology chapter will discuss the limitations of this study.

\section{FOCUS OF STUDY}

The focus of this research practicum was to investigate the dropout rate of the Chapter. This practicum was not designed to prove or disprove any preconceived hypotheses but rather to gather preliminary information. The data obtained will be presented in a descriptive style.

During the preliminary phase of the study, seven basic research questions were compiled. These questions were utilized as a basis from which the questionnaire utilized in this study was developed. Since the research by the Ohio Chapter, NASW was obtained late in the process of doing this research practicum, it was not possible to utilize it as a baseline for the research questions. The research questions are as follows: 
1. Is there a relationship between the high financial requirement of dues and the drop-out rate of the Chapter?

2. Is there a relationship between the members' dissatisfaction with the organizations expenditure of funds and the drop-out rate of the Chapter?

3. Is there a relationship between members' belief that there is an overemphasis on professional prestige or social issues and the drop-out rate of the Chapter?

4. Is there a relationship between members' belief that the Chapter is ineffective in promoting legislation and the drop-out rate of the Chapter?

5. Is there a relationship between a perceived lack of leadership within the Chapter and the drop-out rate of the Chapter?

6. Is there a relationship between a perceived lack of opportunity to participate in the decisionmaking process within the Chapter and the dropout rate of the Chapter?

7. Is there a relationship between other causes, i.e., moving and leaving the profession of social work and the drop-out rate of the Chapter?

QUESTIONNAIRE PRE-TEST

A pre-test of the questionnaire utilized in this study was conducted in November of 1978. The questionnaire was given to four former members of the Chapter. The pre-testing of the questionnaire took one week to complete. Minor modifications based on suggestions of pre-test respondents were made. The changes made were in rewording of the questions to attain greater clarity. A copy of the pre-test questionnaire can be found in Appendix A. 


\section{POPULATION}

The population used in this study was composed of members who had terminated their membership with the Chapter between the period of March of 1977 to March of 1978. With the Chapter's approval and assistance, names and addresses of terminated members were obtained from membership rosters. The process of securing names and addresses began in March of 1978 and continued through November of 1978. This seven-month period was necessary to guarantee that terminated members had not reinstated with the Chapter. Names and addresses of those members who had terminated their membership between March of 1977 to March of 1978 were checked against the rosters for the months of July of 1978 and October of 1978. These two rosters show the reinstatement status of members by indicating if members have paid their dues.

During the preliminary phase of the name search, a total of ninety-one names and addresses of terminated members were obtained. At the conclusion of the name search, it was found that twenty-five of these ninety-one members had been reinstated. Therefore, the total number of terminated members during the period of March of 1977 to March of 1978 was tallied at sixty-six, which is nine percent of the total membership (715) for that period. The Chapter does not have records prior to this time. So, it was not possible to determine if this was an excessive drop-out rate. From these sixty-six names, thirty-three were randomly selected and comprise the sample utilized in this study. 


\section{INSTRUMENT}

Data for this research practicum were collected by a selfadministered questionnaire. The questionnaire was basically an attitudinal survey. Its secondary purpose was to obtain indications of members' knowledge of the organizational functioning of the Chapter.

The questionnaire was seven pages in length and contained thirtytwo questions. The questions were multiple choice and respondents were requested to mark the box which answered the question best for them. Respondents were requested to read each question carefully before indicating a response. In addition, they were also advised that the questions on the questionnaire pertained to the Chapter only and not NASW as a whole. Space was provided at the end of the questionnaire for comments and elaboration on issues. A copy of the questionnaire can be found in Appendix C.

Each questionnaire was assigned a three digit code number. This coding system permitted identification of respondents who did not return the questionnaire so that a follow-up letter could be sent to encourage these respondents to complete the questionnaire.

A key for the coding system was developed. When a questionnaire was returned, it was compared with the key and the corresponding. number was checked off, making it possible to rapidly calculate the number of questionnaires returned.

The questionnaire was divided into four major categories. They were: 1) pre-questionnaire screening, 2) demographic characteristics of members, 3) members' attitudes toward and knowledge of the Chapter, 
and 4) summary and comments. A description of these sections will be presented.

The first category of questions was designed to separate from the sample those members who had moved to another state or who had left the profession of social work. Respondents were asked if their reason for membership withdrawal was because they had moved to another state or because they had left the profession of social work. If respondents answered "yes" to either question, it was not necessary for them to complete the questionnaire because their reason for withdrawal was not a reaction to the Chapter's functioning. If respondents answered "no" to both questions, they were instructed to complete the questionniare. The second category of questions was aimed at identifying demographic characteristics of respondents. Data were sought in the following areas: sex, age, marital status, personal income level per year, and education level. In addition, information was sought regarding respondents' employment status at the time of withdrawal. Respondents were requested to indicate how many years experience they had as a social worker and how many years they had belonged to the Chapter. Fina1ly, respondents were asked if they planned to rejoin the Chapter.

It was noted during tabulation that a typographical error had occurred in a response category to the question asking for years of experience as a social worker. The error occurred in the first range of years. The category appeared on the questionnaire as covering the years of one to five. It should have read one to four. Since all respondents answered the second part of the question which requested that they specify the number of years experience, it was possible to place them into the category as if it read one to four. 
The same error occurred in the question asking for years as a member of the Chapter. Three respondents did not specify the number of years; therefore, it was not possible to categorize them in the one to four year range. They did, however, fall into the combined range of one to nine years.

The third category of questions was designed to probe respondents' attitudes toward and knowledge of the Chapter. Attitudes were probed in the areas of: membership dues, benefits, social issues, professional prestige, allocation of funds, legislation supported by the Chapter, leadership, channels of input to the Chapter and responsiveness by the Chapter to members' concerns. Knowledge was requested in the areas of: fund allocation, legislation and organizational structure.

The fourth category contained a summary question which asked respondents to 1 ist and rank the three most important reasons for their withdrawal from the Chapter. Space was provided at the end of the questionnaire for comments and elaboration of ideas.

\section{COLLECTION OF DATA}

After revisions were made of the pre-test questionnaire, each respondent was sent a questionnaire packet on December 1, 1978. Each questionnaire packet contained a cover letter, a questionnaire and a stamped, return-addressed envelope for the completed questionnaire. Respondents were encouraged to return the completed questionnaire within two weeks of receipt of the questionnaire packet. A copy of the cover letter can be found in Appendix B. 
Two weeks after the initial mailing of the questionnaires, seventeen completed questionnaires were returned. An additional fourteen questionnaires were returned by the postal service as undeliverable as addressed. It was possible to locate four of these respondents through the telephone directory. After contacting these persons by phone, completed questionnaires were received from them. This resulted in a return rate of twenty-one questionnaires. One additional respondent reached by telephone refused to complete and return the questionnaire, saying it was "too personal".

At the end of the two-week period following the first mailing of the questionnaire, a follow-up letter and another questionnaire were mailed to nonrespondents. This second mailing produced one more questionnaire resulting in a return rate of twenty-two questionnaires. A copy of the follow-up letter can be found in Appendix B.

Because it was thought that no further questionnaires would be returned, analysis of data began in January of 1979; however, in March of 1979 one more questionnaire was returned. This final questionnaire resulted in a total response rate of twenty-three or seventy percent of the original thirty-three. The results presented in the following chapter are based on a sample of twenty-three. The response rate might have been higher if it had been possible to obtain addresses for the remaining ten respondents.

\section{LIMITATIONS OF THE STUDY}

The most obvious limitation of this study was the sample size. Because the sample was very small, it was not possible to utilize the 
Chi-square test in data analysis as had been planned. In early planning, consideration was not given to how many respondents would be screened out in the pre-questionnaire screening segment of the questionnaire. Therefore, the combined group of nonrespondents and those screened out in the pre-questionnaire screening reduced the sample size from thirty-three to sixteen.

Another limitation is that generalizations cannot be made from the sample population in this practicum to withdrawn members of other Chapters. The sample is only representative of the Oregon Chapter, NASW.

A third limitation was the survey instrument. The questionnaire utilized in this study was exploratory and had not been used previously. Therefore, there was no way to test the reliability of the instrument or the validity of the data collected.

Other limitations existed in the questionnaire itself. Some of the questions were ambiguous. Some areas of information were probed more fully than others; hence, the questionnaire lacked consistency. Finally, the subject of drop-out rates of organizations is limited itself. There is little information and research in this area. 
CHAPTER IV

RESULTS

The purpose of this study was to investigate the drop-out rate of the Chapter between March of 1977 to March of 1978. This research was not designed to prove or disprove any preconceived hypotheses about that rate. The items on the questionnaire were primarily exploratory in nature. The study results will be presented in categories of related information and an analysis of the results will follow.

\section{PRE-QUESTIONNAIRE SCREENING}

The questions in this category were designed to separate from the sample those members who had moved to another state or those who had left the profession of social work. Responses to these questions were based on a sample size of twenty-three respondents.

The first question, which asked if respondents had moved to another state, produced twenty-one negative responses (ninety-one percent) and two nonresponses (nine percent). One of the nonrespondents indicated that a move had been made but the move was not the reason for withdrawal. The second part of this question asked if the respondent had rejoined NASW in another state. Response to this part of the question showed that twenty-two (ninety-six percent) had not rejoined. One person did not respond (four percent). 
With regard to the leaving of the profession of social work, the responses differed from those in the previous question. Here it was found that six members (twenty-six percent) had left the profession of social work and thereby withdrew from the Chapter. The majority, seventy percent, did not leave the profession of social work. See Table I for a breakdown of the actual figures.

\section{TABLE I}

MEMBERS WHO WITHDREW FROM OREGON CHAPTER, NASW

AS A RESULT OF LEAVING THE PROFESSION OF SOCIAL WORK, BY NUMBER AND PERCENT

\begin{tabular}{lcc}
\hline Left the profession & Number & Percent \\
\hline Yes & $6 *$ & 26 \\
No & 16 & 70 \\
Nonresponse & 1 & 4 \\
\hline TOTAL & 23 & 100 \\
Two of these respondents indicated that they had retired.
\end{tabular}

The nonrespondent shown in Table I returned the questionnaire unanswered, with written comments pertaining to his/her reasons for withdrawing. These comments are included at the end of this chapter.

The remainder of the questionnaire was completed by the sixteen persons (seventy percent) responding in the negative to both questions. That is, their reasons for withdrawing were something other than moving or leaving the profession of social work. Thus, all remaining analyses are based on a sample size of sixteen. 
DEMOGRAPHIC DATE

The next category of information was that of demographic data. Each demographic item will be presented under the appropriate subheading.

$\underline{\text { Sex }}$

In analyzing the results, it was found that there were slightly more male respondents than female respondents. Nine (fifty-six percent) were male and seven (forty-five percent) were female.

$\underline{\text { Age }}$

It was found that the majority belonged to the age range of thirty to thirty-nine years; eleven (sixty-nine percent) belonged to this category. Three (nineteen percent) fell in the category of twenty to twenty-nine years and two (twelve percent) were between the ages of forty to forty-nine years.

\section{Marital Status}

Analysis here showed that ten respondents (sixty-two percent) were married. This was the largest group in this category. Singles and those indicating other followed with two (twelve percent) in each group. The smallest groups were those of the separated and divorced. See Table II for an illustration of these figures.

Personal Income Level Per Year

Twelve respondents (seventy-five percent) had incomes ranging from less than $\$ 10,000$ per year to $\$ 19,999$ per year. The remaining respondents had incomes falling between $\$ 20,000$ per year and $\$ 29,999$ per year. For a more detailed breakdown see Table III. 
TABLE II

MARITAL STATUS OF MEMBERS WHO WITHDREW FROM OREGON CHAPTER, NASW, BY NUMBER AND PERCENT

\begin{tabular}{lcc}
\hline Marital Status & Number & Percent \\
\hline Single & 2 & 12 \\
Married & 10 & 62 \\
Separated & 1 & 6 \\
Divorced & 1 & 6 \\
Other* & 2 & 12 \\
\hline Total & 16 & $98 * *$ \\
One respondent indicated a status of widowhood. & \\
** Error due to rounding &
\end{tabular}

TABLE III

PERSONAL INCOME LEVEL PER YEAR OF MEMBERS WHO WITHDREW FROM OREGON CHAPTER, NASW, BY NUMBER AND PERCENT

Personal Income Level

Number

Under $\$ 10,000$

$\$ 10,000-\$ 14,999$

$\$ 15,000-\$ 19,999$

$\$ 20,000-\$ 24,999$

$\$ 25,000-\$ 29,999$

$\$ 30,000$ and above

TOTAL

* Error due to rounding
Percent

25

25

25

12

12

$0 \quad 0$ 
Educational Level

It was found that most respondents held MSW degrees. Thirteen (eighty-one percent) held this degree. Two (twelve percent) held BA degrees and one respondent (six percent) indicated other and specified that the degree held was an M.Ed. and work was being done on an M.S.

\section{Employment in a Social Service Capacity}

Eleven respondents (sixty-nine percent) indicated that they had been employed in a social service capacity at the time they withdrew from the Chapter. This group of respondents were then asked if they had been employed full or part-time. All eleven (one hundred percent) indicated they had been employed full-time. This group of respondents was also requested to indicated their job description at the time of withdrawal. Four (thirty-six percent) had been employed in direct service and five (forty-five percent) had been employed in administration. Respondents were not instructed to give one response only; therefore, two categories were added to accommodate those respondents whose job descriptions were covered by two titles. One respondent (nine percent) had been employed in an administrative and consultation capacity and another respondent (nine percent) was employed in direct service combined with planning.

Respondents who had not been employed in a social service capacity when they withdrew totaled five (thirty-one percent). This group of respondents was requested to indicate what their situation was at the time of withdrawal. The number of those unemployed was three (sixty percent). There was one student (twenty percent) and one respondent (twenty percent) was employed in a capacity other than social service. 
Years of Experience as a Social Worker

It was found that seven respondents (forty-five percent) had one to four years experience. The next category of five to nine years included six respondents (thirty-eight percent) while the final category of ten to fourteen years showed a response rate of three persons (nineteen percent). Respondents were asked to indicate the exact number of years they had experience as social workers. In reviewing these responses, it was determined that the average was 6.7 years for the total sample and the median was 6.8 years.

\section{Years as a Member of the Chapter}

Three respondents did not specify how many years they had been a member and, due to the previously mentioned typographical error, could not be categorized. Of the remaining respondents, eleven had belonged one to four years and two respondents had belonged five to nine years. It was possible to ascertain that all sixteen members fell within the range of one to nine years.

Respondents Plans with Regards to Rejoining the Chapter

Many respondents indicated that they did not intend to rejoin; however, many were also undecided. Specifically, seven (forty-four percent) responded that they did not plan to rejoin and six (thirtyeight percent) were undecided. Only three (nineteen percent) indicated a desire to rejoin. Therefore, it would appear that many respondents' reasons for withdrawing were strong enough to prevent them from rejoining. 
KNOWLEDGE AND ATTITUDES

The third category of investigation was that of knowledge of and attitudes toward the Chapter. Again information will be presented under subheadings which group together questions aimed at related areas of information. 'These areas have been derived from the original research questions.

\section{Membership Dues}

In this category, respondents were first asked if they had withdrawn as the result of membership dues. A majority responded yes to this question; fourteen (eighty-eight percent) said they withdrew because of membership dues. Only two (twelve percent) said they had not withdrawn for this reason. None of the respondents were undecided on this issue.

Respondents were then asked to specify what level of dues would be acceptable to them if they had withdrawn as the result of membership dues. The majority of this group of fourteen believed that less than $\$ 20.00$ per year would be acceptable to them. The maximum range indicated was $\$ 65.00$ per year to $\$ 79.00$ per year. The breakdown, showing responses to an acceptable level of dues, can be seen in Table IV.

The next question asked respondents if they believed their membership dues had brought satisfactory benefits. The majority responded no to this question; that is, eleven (sixty-nine percent) answered that they believed their dues did not bring satisfactory benefits. Of the remaining respondents, two (twelve percent) responded that they believed their dues did bring satisfactory returns, while three (nineteen percent) 
responded that they believed their dues brought somewhat satisfactory benefits. Again no respondents were undecided on this matter.

\section{TABLE IV}

ACCEPTABLE LEVEL OF DUES AS INDICATED BY MEMBERS WHO WITHDREW FROM OREGON CHAPTER, NASW, AS A RESULT OF THE HIGH COST OF DUES, BY NUMBER AND PERCENT

Leve1 of Dues

Number

Percent

Under $\$ 20.00$

$\$ 20.00-\$ 34.00$

$\$ 35.00-\$ 49.00$

$\$ 50.00-\$ 64.00$

$\$ 65.00-\$ 79.00$

$\$ 80.00-\$ 94.00$

$\$ 95.00$ and over

TOTAL

14

\section{7}

14

3

21

0

0

1 7

0

0

* Error due to rounding

In relation to benefits provided through the Chapter, respondents were further asked which of these benefits, if any, they utilized. It was found that nine (fifty-six percent) did not utilize any of the benefits and seven (forty-four percent) did. Respondents were permitted to indicate more than one response. Table $\mathrm{V}$ illustrates benefits utilized by respondents. 
TABLE V

BENEFITS UTILIZED BY MEMBERS WHO WITHDREW FROM

OREGON CHAPTER, NASW, BY NUMBER AND PERCENT

Benefits

Number

Percent

Professional Liability

2

10

Insurance

Oregon Social Work Job

0

0

Bank

Life and Health

1

5

Insurance

Social Work Vocational

1

5

Bureau

Purchase of Books

2

10

Periodicals

0

0

Workshops

4

21

None

9

47

TOTAL

19

$98 *$

* Error due to rounding.

With regard to social betterment for their clients, a majority of eleven (sixty-nine percent) responded that they did not believe that their clients received any social betterment as a result of dues paid. An even larger number, fourteen respondents (eighty-eight percent), did not believe their employment setting received social betterment. Only one respondent (six percent) expressed a belief that clients and employment setting received social betterment because of membership dues. Those respondents who were undecided regarding their belief that 
membership dues brought satisfactory social betterment for their clients totaled four (twenty-five percent). A smaller number of two (twelve percent) was undecided as to whether their dues brought satisfactory social betterment for their employment setting.

\section{Chapter Funds}

A group of seven respondents (forty-four percent) indicated that guidelines for the expenditure of funds were not made known to them. Many were uncertain regarding this issue. A total of six (thirty-eight percent) was uncertain. On1y three (nineteen percent) indicated that guidelines for the expenditure of funds were made known to them.

With regard to fund allocation, eleven (sixty-nine percent) indicated they did not know how funds were allocated. Three (nineteen percent) were uncertain and two (twelve percent) were somewhat dissatisfied.

\section{Professional Prestige and Social Issues}

The next group of questions was designed to get at views regarding the relationship of the Chapter to professional prestige and social issues. Analysis indicated that forty-four percent of respondents believed the Chapter was either concerned or very concerned with professional prestige. Nineteen percent believed the Chapter was not concerned. A sizeable group of twenty-five percent was undecided. See Table VI for a detailed breakdown of respondents' attitudes regarding the Chapter's concern with professional prestige. 
TABLE VI

ATTITUDES OF MEMBERS WHO WITHDREW FROM OREGON CHAPTER, NASW, REGARDING THE CHAPTER'S CONCERN WITH PROFESSIONAL PRESTIGE, BY NUMBER AND PERCENT

Concern With Pro-

fessional Prestige
Number

3

4

3

4

2 16
Percent

19

25

19

25

12

TOTAL 100

Similarly, respondents were requested to indicate if they believed the Chapter was overly concerned with the promotion of social issues. A large group of fifty percent of respondents indicated that they believed the Chapter was not concerned with social issues. Thirtyone percent indicated a belief that the Chapter was either concerned or very concerned. See Table VII for a display of the findings.

When asked to indicate which the Chapter should be concerned with, professional prestige or social issues, these two combined, or neither, it was found that respondents believed the Chapter should be concerned with social issues and social issues combined with professional prestige. No respondents believed the Chapter should be concerned with professional prestige alone. A sizeable group of four respondents (twenty-five percent) did not respond to the question. See Table VIII for a detailed breakdown of results. 
TABLE VII

ATTITUDES OF MEMBERS WHO WITHDREW FROM OREGON CHAPTER, NASW, REGARDING THE CHAPTER!S CONCERN WITH SOCIAL ISSUES, BY NUMBER AND PERCENT

\begin{tabular}{lcr}
\hline $\begin{array}{l}\text { Concern With } \\
\text { Social Issues }\end{array}$ & Number & Percent \\
\hline Very Concerned & 1 & 6 \\
Concerned & 4 & 25 \\
Not Concerned & 8 & 50 \\
Undecided & 1 & 6 \\
No Response & 2 & $99 *$ \\
\hline Error due to rounding & 16 & \\
\hline
\end{tabular}

TABLE VIII

ATTITUDES OF MEMBERS WHO WITHDREW FROM OREGON CHAPTER, NASW, REGARDING WHAT THE CHAPTER SHOULD BE CONCERNED WITH IN RELATION TO PROFESSIONAL PRESTIGE AND SOCIAL ISSUES, BY NUMBER AND PERCENT

Concern with Professional

Prestige and Social Issues

Number

Percent

Professional Prestige

Professional Prestige

and Social Issues

Neither Professional

Prestige nor Social Issues

No Response

TOTAL
0

6

5

0

38

31

1

6

425 
Legislation

Within this area, it was found that fourteen respondents. (eightyeight percent) had some knowledge of legislation supported by the Chapter. Two (twelve percent) had no knowledge at all. See Table IX for a further breakdown of this information.

\section{TABLE IX}

KNOWLEDGE OF LEGISLATION SUPPORTED BY THE CHAPTER AS INDICATED BY MEMBERS WHO WITHDREW FROM OREGON CHAPTER, NASW, BY NUMBER AND PERCENT

\begin{tabular}{lcc}
\hline Knowledge of Legislation & Number & Percent \\
\hline Considerable Knowledge & 3 & 19 \\
Knowledge in General & 7 & 44 \\
Limited Knowledge & 4 & 25 \\
No Knowledge & 2 & 12 \\
\hline TOTAL & 16 & 100 \\
\hline
\end{tabular}

In pursuing this further, it was found that a clear majority believed the Chapter was involved in the promotion of legislation. Their numbers totaled twelve (seventy-five percent). None of the respondents believed the Chapter was uninvolved and four (twentyfive percent) were undecided.

Finally, with regards to satisfaction with legislation supported, most respondents indicated that they were somewhat satisfied or undecided. Those who were somewhat satisfied totaled six (thirty-eight percent) as did those who were undecided. No respondent indicated 
satisfaction and three (nineteen percent) indicated they were not satisfied. These results can be seen in Table $\mathrm{X}$.

\section{TABLE X}

SATISFACTION WITH LEGISLATION SUPPORTED BY THE

CHAPTER AS INDICATED BY MEMBERS WHO WITHDREW

FROM OREGON CHAPTER, NASW

BY NUMBER AND PERCENT

Satisfaction with

Legislation

Number

Percent

Satisfied

Somewhat Satisfied

Not Satisfied

Undecided

No Response

TOTAL

16
0

38

19

38

6

$101 *$

* Error due to rounding

Respondents were asked to indicate their knowledge of the organizational structure of the Chapter. It was found that eight (fifty percent) had limited knowledge; however, seven (forty-four percent) believed they had general knowledge. Only one person (six percent) indicated no knowledge.

In the realm of leadership, respondents were requested to indicate if they withdrew as the result of a lack of leadership within the Chapter. Most respondents, ten (sixty-two percent) indicated they did not withdraw for this reason. Only two (twelve percent) indicated 
that they withdrew due to a lack of leadership. The same number were undecided. It appears that the Chapter's leadership during the time period of March of 1977 to March of 1978 was satisfactory. See Table $\mathrm{XI}$ for details.

\section{TABLE XI}

MEMBERS WHO WITHDREW FROM OREGON CHAPTER, NASW, AS A RESULT OF A LACK OF LEADERSHIP, BY NUNBER AND PERCENT

\begin{tabular}{lcc}
\hline Lack of Leadership & Number & Percent \\
\hline Yes & 2 & 12 \\
No & 10 & 62 \\
Undecided & 2 & 12 \\
No response & 2 & 12 \\
\hline TOTAL & 16 & $98 *$ \\
\hline Error due to rounding & & \\
\hline
\end{tabular}

Member Input

Because voting can be a channel of participation, respondents were requested to indicate if they had voted on Chapter issues when they were members. It was found that most respondents voted sometimes. A total of nine respondents (fifty-seven percent) voted sometimes or always. On the other hand, six respondents (thirty-eight percent) voted seldom or never. It appears that members did participate by voting. See Table XII for a breakdown of results. 
TABLE XII

THE EXTENT TO WHICH MEMBERS, WHO WITHDREW FROM OREGON CHAPTER, NASW, VOTED ON CHAPTER ISSUES, BY NUMBER AND PERCENT

\begin{tabular}{lcc}
\hline Voted on Issues & Number & Percent \\
\hline Always & 3 & 19 \\
Sometimes & 6 & 38 \\
Seldom & 3 & 19 \\
Never & 3 & 19 \\
No Response & 1 & 6 \\
\hline TOTAL & 16 & $101 *$ \\
E Error due to rounding & & \\
\hline
\end{tabular}

Next, respondents were presented with four channels of participation in the Chapter. They were requested to indicate which channels they believed were available to them as a means of giving input to the Chapter. Respondents were allowed to mark more than one response. Respondents most often indicated that voting was a channel of participation. Respondents were given a category of other in which they could specify other channels of participation. This category was indicated by three respondents. One respondent indicated a belief that input as a member was met through all of the other options: voting, attending Chapter meetings, and participating on a committee. On the other hand, one respondent stated a belief that none of the other channels were open as means of participation. The third respondent simply stated 
that this matter was not considered. Table XIII shows how respondents answered this item.

TABLE XIII

PERCEPTIONS REGARDING CHANNELS OF PARTICIPATION IN THE CHAPTER AS INDICATED BY MEMBERS WHO WITHDREW FROM OREGON CHAPTER, NASW, BY NUMBER AND PERCENT

Means of Participation

Number

Percent

Voting

10

40

Attending Chapter

Meetings

5

20

Participating on a

Committee

5

20

Other

3

12

No Response

2

8

TOTAL

25

100

In relation to members' concerns, a clear majority of eleven (sixty-nine percent) indicated that they did know how to make their concerns known. A smaller number, three (nineteen percent), stated that they did not know how to make their concerns known. Two respondents (twelve percent) were undecided.

In this same area, respondents were asked if they believed the Chapter was responsive to the concerns of a majority of its members. Here the majority of respondents, nine (fifty-six percent), was undecided. The other respondents were fairly evenly split, with three respondents (nineteen percent) indicating a belief that the Chapter 
was responsive and four (twenty-five percent) indicating that the Chapter was not responsive.

\section{SUMMARY AND COMMENTS}

In a final attempt to summarize respondents reasons for dropping their membership, it was required that respondents list the three most important reasons for their withdrawal. It was learned that only seven respondents followed the instructions and prioritized the three most important reasons for their withdrawal. The remaining respondents failed to rank or prioritize their responses. Therefore, all responses were analyzed without the assigning of priorities. It must be noted that respondents indicated more than one response.

The reasons given most frequently for withdrawal was the cost of dues. Respondents indicated this ten times (twenty-nine percent). Next were inadequate benefits and the category of other, each listed five times (fourteen percent). Ineffectiveness in promoting legislation and overemphasis on professional prestige were listed four times each (eleven percent). The allocation of funds, overemphasis on social issues, lack of leadership, lack of opportunity to participate and lack of responsiveness to members' needs were listed less frequently. See Table XIV for this analysis.

As can be seen in Table XIV, five respondents indicated other as a reason for withdrawal. All five persons clearly specified their intentions. One respondent stated that the Chapter lacked power or strength in securing jobs and pay. Similarly, another respondent stated, "A lot of money is paid for membership, but the benefits do 
not meet my needs other than the journal." The third respondent indicated disagreement with NASW's policy of representing all social workers. This person believed NASW should represent MSW and ACSW social workers only. It was not specified whether this was at the Chapter or national level. The fourth respondent expressed dissatisfaction that there was not a local Chapter in the small town where this person resides. The respondent stated that the nearest office was sixty-seven miles away. The final respondent believed the Chapter was too far away geographically and saw no personal benefit. In addition, this respondent believed there was no opportunity or prestige for the person at the BA level.

Space was provided at the end of the questionnaire so that respondents could comment and elaborate on their reasons for withdrawal from the organization. Within these comments, themes appeared which were similar to those expressed in the last question on reasons for withdrawa1. Seven respondents (forty-four percent) made comments. Two respondents commented on the cost of belonging to the Chapter. One respondent found it impossible to pay the dues after graduate school because of unemployment. This person believed the dues should be waived prior to employment. The other respondent believed the dues to be a luxury when there were three other persons in his/her family to support on a very small salary. This person expressed frustration with the fact that NASW can write about wage scales, but to this person this is only a "paper tiger". It was not specified whether this was at the Chapter or national level. 
TABLE XIV

REASONS FOR WITHDRAWAL FROM THE CHAPTER AS INDICATED

BY MEMBERS WHO WITHDREW FROM OREGON CHAPTER, NASW, BY NUMBER AND PERCENT

\begin{tabular}{|c|c|c|}
\hline Reasons for Withdrawal & Number & Percent \\
\hline High Cost of Dues & 10 & 29 \\
\hline Inadequate Benefits & 5 & 14 \\
\hline Allocation of Funds & 1 & 3 \\
\hline $\begin{array}{l}\text { Overemphasis on Pro- } \\
\text { fessional Prestige }\end{array}$ & 4 & 11 \\
\hline $\begin{array}{l}\text { Overemphasis on } \\
\text { Social Issues }\end{array}$ & 1 & 3 \\
\hline $\begin{array}{l}\text { Ineffectiveness in Pro- } \\
\text { moting Legislation }\end{array}$ & 4 & 11 \\
\hline Lack of Leadership & 2 & 6 \\
\hline $\begin{array}{l}\text { Lack of Opportunity } \\
\text { to Participate }\end{array}$ & 1 & 3 \\
\hline $\begin{array}{l}\text { Lack of Responsiveness } \\
\text { to Members' Needs }\end{array}$ & 2 & 6 \\
\hline Other & 5 & 14 \\
\hline TOTAL & 35 & 100 \\
\hline
\end{tabular}

Two other respondents commented on the previously mentioned distance factor. One of these respondents believed that his/her input was not sought because only a long distance phone number was given in newsletters, with no address. The other respondents believed the Chapter was inaccessible to members residing outside Portland. This respondent also stated that NASW on the national level is "largely irrelevant". 
The remaining two respondents brought up issues which were not touched upon by the questionnaire. One person expressed the belief that the organization was going in too many directions with little power or influence over professionals. The final respondent described several areas which could help make membership more attractive. They were: program exchange, workshops, innovative treatment modes and services, and coordination with other organizations.

It was mentioned at the beginning of this chapter that one respondent returned the questionnaire without completing it. A statement was included about this respondent's reason for withdrawing. This person disagreed with NASW's stand on abortion. The respondent realizes that it is disadvantageous professionally not to belong, but believes his/her stance on abortion cannot be compromised.

\section{ANALYSIS}

It was found that twenty-six percent of those withdrawing their membership from the Chapter resulted from leaving the profession of social work. That is, their reasons for withdrawing were not necessarily a reaction to the Chapter or its functioning. The majority of those withdrawing did so as the result of their attitudes toward the Chapter.

In analyzing the data, several important factors stand out. Before going into these, a composite picture of those respondents who withdrew will be presented. The picture has been derived from salient features within the demographic data. The individual being described may be either male or female, is married, and holds an MSW degree. 
This person's income ranges from under $\$ 10,000$ per year to $\$ 19,999$ per year. The person was employed full-time in direct service or administration. The person has one to nine years' experience as a social worker and has belonged to the Chapter between one to four years. The person either does not plan to rejoin the Chapter or is undecided.

An important phenomenon to be noted from the above data is that those persons in our sample were practicing in the field of social work for longer periods of time than they were members of the Chapter. In fact, they had worked almost twice as many years as they had belonged to the Chapter. It is possible that some of these respondents had belonged to Chapters in other states. Cost may have been a factor at some point in the careers of these members.

The major factor which stands out in this study is that the majority of the respondents withdrew from the Chapter as the result of the high cost of dues. When this factor was presented along with others, respondents gave this most frequently as their reason for withdrawal. The cost to these members at the time they withdrew was $\$ 60.00$ per year for a regular member: Most respondents indicated that less than $\$ 20.00$ per year was an acceptable level of dues for them, significantly less than the rate at which they were assessed. In comparing this with the results of the Ohio Chapter study, it was found that the cost of dues was given as the second most important reason for withdrawal in that study. The most important was retirement.

In relation to the topic of dues, over half of the respondents indicated a belief that the dues they paid did not bring satisfactory benefits. However, it must be noted that a smaller percentage (but 
still over half of the respondents) indicated that they did not utilize the benefits available through the Chapter. It should also be noted that most respondents believed their dues did not bring social betterment for their clients or employment setting.

In the area of funds, it was found that most respondents were unaware of guidelines for the expenditure of funds or of the manner in which funds were allocated within the Chapter. This lack of knowledge on the part of respondents made it impossible to assess attitudes, and fund allocation was rarely given as a reason for withdrawal.

With regard to professional prestige and social issues, over onethird of the respondents believed the Chapter was concerned to some degree with professional prestige, but an even larger group of one-half of the respondents expressed the belief that the Chapter was not concerned with social issues. Overemphasis on professional prestige was given frequently as a reason for withdrawal.

When professional prestige and social issues were considered together, it was found that most believed that social issues or social issues combined with professional prestige should be areas of concern for the Chapter. It must also be noted that one-fourth of the respondents did not respond. This was the greatest rate of nonresponse in the entire survey.

Almost all respondents had some knowledge of legislation supported by the Chapter; however, less than half of the respondents were satisfied with the legislation supported. Ineffectiveness in promoting legislation was given frequently as a reason for withdrawal. 
Almost all of the respondents indicated some degree of knowledge of the organizational structure. In addition, most respondents indicated that they did not withdraw because of a lack of Chapter leadership.

The data showed that over two-thirds of the respondents voted on Chapter issues and that respondents listed this most frequently as a channel of participation in the Chapter. However, respondents also indicated that attending Chapter meetings and participating on committees were available options.

Through the comments provided by respondents, it was found that geographical distance was often a factor in a respondent's decision to withdraw. Several respondents indicated that the Chapter was located too far geographically from them. These respondents did not believe their needs were being met through the Chapter.

In summary, the five reasons given most of ten for withdrawal are: the high cost of dues, inadequate benefits, ineffectiveness in promoting legislation, overemphasis on professional prestige, and other. These reasons comprised seventy-nine percent of the total. The remaining reasons of allocation of funds, lack of leadership, lack of opportunity to participate, overemphasis on social issues, and lack of responsiveness to members' needs comprised twenty-one percent of the total. 
CHAPTER V

SUMMARY AND RECOMMENDATIONS

PURPOSE

The purpose of this study was to assess the factors related to the drop-out rate in the Oregon Chapter, NASW. In assessing this drop-out rate, those members who terminated their membership with the Chapter during the period between March of 1977 to March of 1978 were surveyed. The total number of members in the Chapter during this period was six hundred and forty-nine. This figure does not include the sixty-six members who dropped out. This study was primarily exploratory in nature, in that, it was not designed to prove or disprove any preconceived hypotheses but rather to gather preliminary information.

The factors explored with these members were: membership dues, allocation of funds, the Chapter's role in promoting legislatiun, the Chapter's emphasis on professional prestige and/or social issues, leadership within the Chapter, and members' participation in the Chapter. Also, identified were those members who had moved to another state or those who had left the profession of social work.

\section{LITERATURE SUMMARY}

A review of the relevant literature was conducted. In the review of the 1iterature, it was found that there is a scarcity of information 
regarding membership drop-out rates of professional organizations. Within Oregon, there were no studies on drop-out rates located. Specifically, in regards to NASW, only one study was located. This study was by Platt and Kalvin on the Ohio Chapter. The review was able to identify probable factors related to persons dropping their membership in organizations. It was also possible to identify factors which cause people to join organizations.

\section{SUMMARY OF METHODOLOGY}

Since this study was concerned only with the Chapter and not with NASW as a whole, the study was conducted on a statewide basis. The instrument used to obtain data for this study was a self-administered, thirty-two item questionnaire. The questionnaire was basically an attitudinal survey with a secondary purpose of gaining some indication of members' knowledge of the organizational functioning of the Chapter. This questionnaire was sent to a randomly-selected sample of thirty-three members who had terminated their membership between March of 1977 to March of 1978. This sample was drawn from a total of sixty-six members. Twenty-three questionnaires were returned. It is from these twenty-three that the following inferences were made. It must be noted that of these twenty-three, seven had terminated their membership due to leaving the profession of social work rather than as a result of their attitude towards the Chapter or its functioning.

\section{SUMMARY OF FINDINGS}

Respondents to this survey gave five reasons for withdrawal most frequently. These were: high cost of dues, inadequate benefits, 
ineffectiveness in promoting legislation, overemphasis on professional prestige, and other. Less often, respondents indicated that allocation of funds, lack of leadership, lack of opportunity to participate, overemphasis on social issues, and lack of responsiveness to members' needs were reasons for withdrawal.

\section{LIMITATIONS OF STUDY}

Since the sample was small, statistical tests of significance were not utilized. Instead, a calculation of frequency distributions and percentages was done. Therefore, generalizations cannot be made from the sample population in this study to members who terminate their membership in other Chapters. The sample is only representative of the Chapter. Also, the questionnaire utilized in this study was exploratory and had not been used previously. So, there was no way to test the reliability of the instrument or the validity of the data collected. The questionnaire itself also posed some limitations in that it lacked consistency due to the ambiguity of some of the questions and some areas of information were probed more fully than others. A last limitation was in regards to the subject matter itself, in that little information and research have been done in this area.

CONCLUSION

When all of the above factors were presented together, respondents indicated the high cost of dues most frequently as a reason for withdrawal. In light of this factor, future research might probe this area further. Research could evaluate incomes received by social 
workers with the purpose of determining whether incomes are low enough that these persons believe dues are a financial hardship. Another area of investigation in relation to membership dues would be benefits gained from being a member. This practicum showed a dissatisfaction with benefits, but it should also be noted that the majority of those dissatisfied members did not utilize the benefits. The benefits specified on the questionnaire were delineated by the Chapter and may not have coincided with the members' conception of benefits. Future research could be conducted to determine how members perceive benefits and what benefits they see as bringing social betterment for their clients and their employment setting. It is possible that members thought the benefits presently being offered by the Chapter are additional expenses rather than benefits.

From the information obtained in this practicum, it was found that respondents believed the Chapter should be concerned with social issues or social issues and professional prestige. None of the respondents indicated that professional prestige alone should be the only concern. It also appeared that members were reluctant to commit themselves in this area since there was a large group of nonrespondents. This may be reflective of members' hesitancy to admit a desire for professional prestige. Future research in this area could be aimed at defining professional prestige as viewed by social workers with the purpose of determining what adverse effects this has on the Chapter or NASW as a whole.

In the area of legislation, it was found that many respondents were dissatisfied with legislation supported by the Chapter. In 
pursuing this further, research could be designed to determine what kinds of legislation members wish to have supported and how this differs from what the Chapter actually did support. Also it would seem that research might attempt to ascertain why members believe the Chapter is ineffective in promoting legislation. Perhaps the Chapter might design research to evaluate its actual effectiveness in promoting legislation the purpose being to determine if this is a valid area of involvement, or to determine if this area can be strengthened.

The final reason for withdrawal listed by respondents was the category of other. Here a variety of responses emerged, but one which was indicated here frequently was that of geographical distance. Some attention needs to be given to these respondents. The Chapter may wish to determine how many respondents reside outside of the Portland metropolitan area and what are effective ways of serving and meeting the special needs of these members.

This research adds to the developing body of knowledge about drop-out rates in chapters of NASW. At this point in time, a study of this subject matter can only be considered exploratory. Before specific facts regarding this area of investigation can be collectively agreed upon, additional research needs to be conducted and shared with NASW on the national and local levels. It is to such an end that this practicum group presents this study as a baseline for future inquiries. 


\section{BIBLIOGRAPHY}

Beck, Bertram M. "Professional Associations: National Association of Social Workers." In Encyclopedia of Social Work. 17th ed. 2 vols. Edited by John B. Turner. Washington, D.C.: National Association of Social Workers, 1977.

East, Allen. A History of the Oregon Chapter, American Association of Social Workers Until its Merger with the National Association of Social Workers (1921 - 1955). Eugene, Oregon: American Association of Social Workers, Oregon. Chapter, 1956.

Kadushin, Alfred. "Prestige of Social Work - Facts and Factors." Social Work. 3(April 1958): 37-43.

Lindzey, Gardner, and Aronson, Elliott. The Handbook of Social Psychology. 2nd. ed. Reading, Massachusetts: Addison-Wesley Publishing Company, 1968-70.

Napier, Rodney W., and Gershenfeld, Matti K. Groups: Theory and Experience. Boston: Houghton Mifflin Company, 1973.

National Association of Social Workers. The 1978 National Association of Social Workers Professional Social Workers' Directory. Washington, D.C.: National Association of Social Workers, 1978.

Platt, Carol Bowen, and Kalvin, Mary. "Why do Social Workers Terminate their National Association of Social Workers Membership: A Research Project 1974 - 1978." Paper submitted to the National Association of Social Workers. Columbus, Ohio, 29 December 1978.

Pratt, Cynthia W. National Association of Social Workers, Washington, D.C. Telephone interview, February 1979.

Tocqueville, Alexis de. Democracy in America (1835). Translated by Henry Steele Commager. New York: Oxford University Press, 1947. 
Please read each question carefully, then mark the box that answers the question best for you. If a question does not apply to you, please continue to the next question. If you wish to make comments, space is provided at the end of the questionnaire.

1. Did you withdraw from the Oregon Chapter, NASW because you moved?

( ) Yes ( ) No If so, continue with items a and b

a. Where are you currently residing?

b. Have you rejoined the NASW chapter in that state?

() Yes ( ) No

2. Did you withdraw from NASW because you left the profession of social work?

() Yes ( ) No

If you have checked yes to any of the above questions, it is not necessary to complete the questionnaire. Please do return the questionnaire as soon as possible as your response is needed for this study.

3. Sex:

() Male ( ) Female

4. Age:

$\begin{array}{lll}\text { () Under } 21 & \text { ( ) } 21-30 & \text { ( ) } 31-40 \\ \text { ( ) } 41-50 & \text { ( ) } 51-60 & \text { ( ) Over } 60\end{array}$

5. Marital status:

() Single ( ) Married ( ) Divorced. ( ) Widowed

6. Personal income level:

( ) Uner $\$ 10,000$ ( ) $\$ 10,000-\$ 14,999$ ( ) $\$ 15,000-\$ 19,999$

() $\$ 20,000-\$ 24,999$ ( ) $\$ 25,000-\$ 29,999$ ( ) $\$ 30,000$ and above

7. Educational level:

( ) BA
( ) Other (specify) 
8. Were you employed as a social worker when you withdrew from NASW?

( ) Yes If so, continue with items $a$ and $b$

( ) No If not, continue with item c

a. Were you employed:

( ) Part time ( ) Full time

b. What type of job did you perform:

() Direct service (') Planning ( ) Research

( ) Administrative

c. What was your job title at the time of your withdrawal?

9. How many years of experience have you had as a social worker?

(. ) Under 5 years ( ) 5-9 year ( ) 10-14 years

( ) 15-19 year ( ) 20-24 years ( ) 25-29 years

( ) 30-34 years ( ) 35-39 years ( ) Over 40 years

10. How long were you a member of NASW?

$\begin{array}{ll}\text { ( ) Under } 5 \text { years } & \text { ( ) 5-9 years } \\ \text { ( ) 1 ) } 10-24 \text { years } & \text { ( ) over } 25 \text { years }\end{array}$

11. Do you plan to rejoin NASW?

$($ ) Yes ( ) No ( ) Undecided

12. Did you withdraw from NASW as a result of membership dues?

() Yes ( ) No ( ) Undecided

13. If your response to question 12 was yes, what level of dues would have been satisfactory to you?

$\begin{array}{lll}\text { ( ) Under } \$ 20.00 & (\text { ) } \$ 30.00 & \text { ( ) } \$ 40.00\end{array}$

$\begin{array}{lll}\text { ( ) } \$ 50.00 & \text { ( ) } \$ 60.00 & \text { ( ) } \$ 70.00\end{array}$

$\begin{array}{lll}\text { ( }) \$ 80.00 & (\text { ) } \$ 90.00 & (\text { ) Over } \$ 90.00\end{array}$

14. Did you participate in any of the following benefits provided by NASW? (check all that apply)

( ) Profession Liability Insurance

( ) Oregon Social Work Job Bank

( ) Life and Health Insurance

( ) Social Work Vocational Bureau

( ) Books

( ) Workshops

( ) Periodicals (other than the Social Work. Journal)

15. Were guidelines for expenditures of the Oregon Chapter, NASW funds made known to you?

( ) Yes () No ( ) Uncertain 
16. Were you dissatisfied when you were made aware of how the funds were delegated?
( ) Yes
( ) No
( ) Uncertain

17. Did you believe NASW was overly concerned with promoting membership prestige?

() Yes () No ( ) Uncertain

18. Did you believe NASW was overly concerned with promoting social issues?

() Yes () No ( ) Uncertain

19. In your opinion, NASW should have been concerned with:

( ) Membership prestige

( ) Social issues

( ) Membership prestige and social issues

( ) Neither membership prestige or social issues

20. Did you have knowledge of legislature NASW supported during the last year you were a member?
(. ) Yes
( ) No
( ) Uncertain

21. Did you have complete knowledge of NASW's organizational structure?
( ) Yes
( ) No
( ) Uncertain

22. Did you vote on chapter issues when you were a member?
( ) Yes
( ) No
( ) Uncertain

23. Did you believe your input as a member was linited to voting?
( ) Yes
( ) No
( ) Uncertain

24. Did you know how to let NASW know what your concerns were?
(.) Yes
( ) No
( ) Not important

25. Did you believe the organization was responsive to the concerns of a majority of its members?
( ) Yes
( ) No
( ) Uncertain

26. In your opinion, did you believe your dues brought satisfactory benefits?
( ) Yes
( ) No
( ) Somewhat

27. In your opinion, did you believe NASW was involved in the promotion of legislation?
( ) Yes
( ) No
( ) Somewhat

28. Were you satisfied with the legislation NASW supported when you were a member?
( ) Yes
( ) No
( ) Somewhat 
29. Please prioritize your three most important reasons for withdrawing from NASW. ( 1 being the first most important)

( ) High cost of dues

( ) Use of funds

( ) Lack of leadership

( ) Lack of input

(. ) Inadequate benefits

( ) Ineffectiveness in promoting legislation

( ) Over emphasis on membership prestige

( ) Over emphasis on social issues

( ) Lack of responsiveness to members' needs

( ) Other (specify)

Comments : 
APPENDIX B

LETTERS SENT TO STUDY PARTICIPANTS

1630 SW Clay, 非 5 H

Portland, OR 97201

December 1, 1978

We are four graduate social work students from Portland State University who are presently engaging in a study on the membership of the Oregon Chapter of NASW. The purpose of this study is to find out the factors in the decline in the membership in the state of oregon over the past several years as well as to discover some of the strengths of the organization. Hopefully, this study might be helpful to the Oregon Chapter of NASW in developing plans and programs designed to better serve its present and future members. All questions in our questionnaire pertain to the Oregon Chapter only.

We have received sanction from the Oregon Chapter of NASW in obtaining names and addresses of ex-members in the Oregon Chapter. Our findings will be shared with the Oregon Chapter of NASW.

Your name appeared in a scientifically selected random sample. Your answers are very important to the findings of our study. It will take only a short time to answer the questions on the enclosed instrument and return it in the stamped reply envelope. All answers are confidential and will be used strictly for the purpose of this study. The numbered code written on the upper right hand corner of the questionnaire is used to identify non-respondents and will be destroyed when the questionnaire is returned. If the person being addressed is deceased, please indicate on the questionnaire and return it.

Please return the completed questionnaire at your earliest convenience, preferably no longer than two weeks in order for this study to continue according to schedule. Thank you for your help. 
1630 S.W. Clay, \#5H Portland, Oregon 97201 December 15, 1978

I am writing to you regarding the NASW, Oregon Chapter Membership Study questionnaire which was mailed to you on. December 1, 1978. I would like to encourage you to return it at your earliest convenience.

If you have already returned the questionnaire, I wish to thank you and ask you to please disregard this letter.

\section{Sincerely,}


APPENDIX C

FINAL QUESTIONNAIRE

OREGON CHAPTER, NASW MEMBERSHIP STUDY

Please read each question carefully, then mark the box that answers the question best for you. If a question does not apply to you, please continue to the next question. If you wish to make comments, space is provided at the end of the questionnaire.

1. Did you withdraw from the Oregon Chapter, NASW because you moved to another state?

( ) yes ( ) no If no, continue with items a and b.

a. What is your permanent address?

b. Have you rejoined an NASW Chapter in another state?

$$
\text { () yes ( ) no }
$$

2. Did you withdraw from the Oregon Chapter, NASW as a result of leaving the profession of social work?

( ) yes ( ) no

If you have checked yes to either 1 or 2 above, it is not necessary to complete the questionnaire. Please do return the questionnaire as soon as possible as your response is needed for completion of this study. 
3. Sex:

( ) Male (. ) Female

4. Age:
( ) 20-29
( ) $40-49$
( ) 60-69
( ) 30-39
( ) 50-59
( ) 70 and over

5. Marital Status:
( ) Single ( ) Separated ( ) other
( ) Married ( ) Divorced

6. Personal income level per year:

( ) under $\$ 10,000 \quad(\quad) \$ 15,000-\$ 19,999 \quad(\quad) \$ 25,000-\$ 29,999$

( ) $\$ 10,000-\$ 14,999$ ( ) $\$ 20,000-\$ 24,999$ （） $\$ 30,000$ and above

7. Educational level:
( ) BA
( ) DSW
( ) Other (specify)
( ) MSW
( ) Ph.D.

8. Were you employed in a social service capacity when you withdrew from the Oregon Chapter, NASW?

( ) Yes. If so, continue with items $a$ and $b$.

( ) No. If no, continue with item c.

a. Were you employed:
( ) Part time
(. ) Full time

b. Which of the following best describes your job at that time?
( ) Direct service
( ) Planning
( ) other (specify)
( ) Administration
( ) Research 
c. What was your situation at the time of your withdrawal?

$$
\begin{aligned}
& \text { ( ) student ( ) unemployed } \\
& (\text { ) employed in a job other than social services }
\end{aligned}
$$

9. How many years of experience have you had as a social worker?

$$
\begin{array}{llll}
\text { ( ) } 1-5 & \text { ( ) } 15-19 & \text { ( ) } 30-34 \\
\text { ( ) } 5-9 & \text { ( ) } 20-24 & \text { ( ) } 35-39 \\
\text { ( ) } 10-14 & \text { ( ) } 25-29 & \text { ( ) } 40 \text { and over }
\end{array}
$$

Please specify how many years:

10. How many years were you a member of the Oregon Chapter, NASW?

$$
\begin{aligned}
& \text { ( ) } 1-5 \text { ( ) } 10-14 \quad \text { ( ) } 25 \text { and over } \\
& \text { (. ) } 5-9 \text { ( ) 15-24 }
\end{aligned}
$$

Please specify how many years:

11. Do you plan to rejoin the Oregon Chapter, NASW?

$$
(\text { ) yes ( ) no ( ) undecided }
$$

12. Did you withdraw from the Oregon Chapter, NASW as the result of membership dues?

$$
(\text { ) yes ( ) no }(\text { ) undecided }
$$

13. If your response to question 12 was yes, what level of dues would have been acceptable to you?
( ) Under $\$ 20.00$
( ) $\$ 50.00-\$ 64.00$
( ) $\$ 95.00$ and over
( ) $\$ 20.00-\$ 34.00$
( ) $\$ 65.00-\$ 79.00$
( ) $\$ 35.00-\$ 49.00$
( ) $\$ 80.00-\$ 94.00$ 
14. Did you believe your membership dues brought satisfactory professional benefits to yourself?
( ) yes
( ) no
( ) somewhat
( ) undecided

15. Did you participate in any of the following benefits provided by the Oregon Chapter, NASW? (Check all that apply)

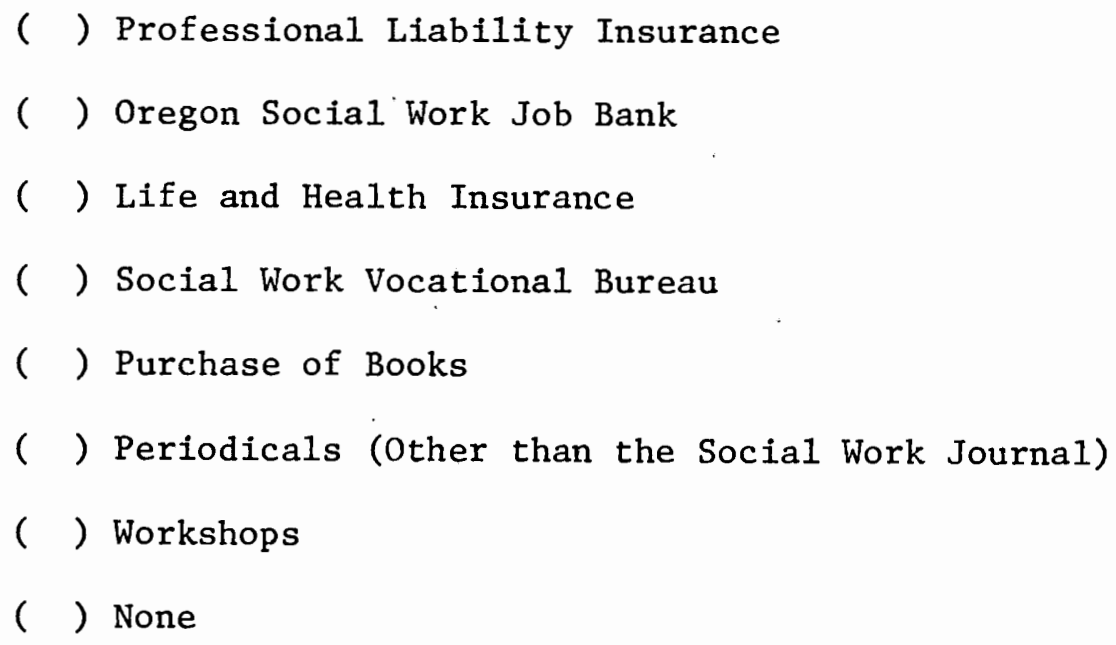

16. Did you believe your membership dues brought satisfactory social betterment for your clients?
( ) yes
( ) no
( ) undecided

17. Did you believe your membership dues brought satisfactory social betterment for your employment setting?
( ) yes
( ) no
( ) undecided

18. Were guidelines for expenditures of the Oregon Chapter, NASW funds made known to you?
( ) yes
( ) no
( ) undecided 
19. Were you dissatisfied when you were made aware of how the funds were allocated?
( ) Dissatisfied
( ) Satisfied ( ) Never knew how
( ) Somewhat dissatisfied
( ) Uncertain they were allocated

20. Did you believe the Oregon Chapter, NASW was overly concerned with promoting professional prestige?
( ) Very concerned
( ) Not concerned
( ) Concerned
( ) Undecided

21. Did you believe the Oregon Chapter, NASW was overly concerned with promoting social issues?
( ) Very concerned
( ) Not concerned
( ) Concerned
( ) Undecided

22. In your opinion, the Oregon Chapter, NASW should have been concerned with:
( ) Professional prestige
( ) Social issues
( ) Professional prestige and social issues
( ) Neither professional prestige nor social issues

23. To what extent did you have knowledge of legislation which the Oregon Chapter, NASW supported during the last year you were a member?
( ) Considerable knowledge
( ) Limited knowledge
( ) Knowledge in general
( ) No knowledge 
24. Did you believe the Oregon Chapter, NASW was involved in the promotion of legislation?
( ) yes
( ) no
( ) undecided

25. Were you satisfied with the legislation the Oregon Chapter, NASW supported when you were a member?
( ) Satisfied
( ) Not satisfied
( ) Somewhat satisfied
( ) Undecided

26. To what extent did you have knowledge of the Oregon Chapter, NASW's organizational structure?
( ) Complete knowledge
( ) Limited knowledge
( ) General knowledge
( ) No knowledge

27. Did you withdraw from the Oregon Chapter, NASW due to lack of leadership?
( ) yes
( ) no
( ) undecided

28. Did you vote on Chapter issues when you were a member?
( ) Always
( ) Seldom
( ) Sometimes
( ) Never

29. Did you believe your input as a member of the Oregon Chapter, NASW was limited to:
( ) Voting
( ) Attending Chapter meetings
( ) Participating on a committee
( ) Other (specify) 
30. Did you know how to let the Oregon Chapter, NASW know what your concerns were?
( ) yes
( ) no
( ) undecided

31. Did you believe the Oregon Chapter, NASW was responsive to the concerns of a majority of its members?
( ) yes
( ) no
( ) undecided

32. Please list the three most important reasons for your withdrawal from the Oregon Chapter, NASW. (Mark 1 for the most important reason.)

( ) High cost of dues

( ) Allocation of funds

( ) Lack of leadership

( ) Lack of opportunity to participate

( ) Inadequate benefits

( ) Ineffectiveness in promoting legislation

( ) Overemphasis on professional prestige

( ) Overemphasis on social issues

( ) Lack of responsiveness to members' needs

( ) Other (specify)

Comments: Please feel free to elaborate on any of the above questions or issues concerning your withdrawal from the Oregon Chapter, NASW. 